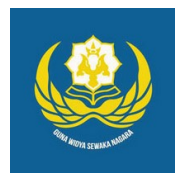

Jurnal Analogi Hukum

Journal Homepage: https://ejournal.warmadewa.ac.id/index.php/analogihukum

\title{
Perlindungan Hukum Badan Pengawas Obat Dan Makanan (BPOM) Terhadap Peredaran Produk Jamu Yang Mengandung Bahan Kimia Obat Berbahaya
}

\author{
Ni Kadek Ayu Padmi Ari Sudewi*, I Nyoman Putu Budiartha dan Ni Made Puspasutari Ujianti
}

Fakultas Hukum, Universitas Warmadewa, Denpasar-Bali, Indonesia

*arisudewi@gmail.com

\begin{abstract}
How To Cite:
Sudewi, N. K. A. P. A., Budiartha, I. N. P., \& Ujianti, N. M. P. (2020). Perlindungan Hukum Badan Pengawas Obat Dan Makanan (BPOM) Terhadap Peredaran Produk Jamu Yang Mengandung Bahan Kimia Obat Berbahaya. Jurnal Analogi Hukum. 2(2). 246-251. Doi: https://doi.org/10.22225/ah.2.2.1928.246-251

Abstract-Traditional medicine in Indonesia or Jamu has been known for a long time. If in traditional medicine contains medicinal chemicals it is where there is an indication of violation of the rules of manufacture or composition of traditional medicines produced. This situation creates unrest among the people as consumers, because its rights have been violated. Weak consumer positions are weakening. Based on the background of the problem described above. Then can be formulated some of the following problems (1) How is the role of BPOM in the supervision of traditional herbal medicine that contains hazardous chemicals in the community? 2 How is legal protection against the public against the traditional herbal medicine that contains harmful chemicals under Law No. 8 of 1999 about consumer protection? Referring to the formulation of the problem, then the type of research used in the writing is normative research. Surveillance conducted by BPOM on the distribution of traditional herbal medicine is done both in production activities where the product has not circulated or supervision of products that have been circulating the market. The legal purpose of repressive legal protection is to resolve disputes. BPOM's preventive law efforts in the supervision of traditional herbs can be coaching and quality improvement policy by enforcing the standardization of production quality.
\end{abstract}

Keywords: Traditional Herbal Medicine, Consumer Protection, BPOM

Abstrak-Keberadaan obat tradisional yang dikenal juga dengan nama jamu tradisional telah sering dikonsumsi dan dipergunakan oleh masyarakat Indonesia. Namun apabila dalam kandungan jamu terdapat kandungan bahan kimia obat dapat dipastikan bahwa jamu tersebut tidak layak untuk dikonsumsi. Hal tersebut menimbulkan keresahan di kalangan masyarakat yang mengkonsumsi jamu sebagai minuman sehar-harinya. Posisi konsumen yang lemah semakin melemah. Berdasarkan latar belakang masalah yang telah diuraikan tersebut diatas. Maka dapat dirumuskan beberapa permasalahan sebagai berikut (1) Bagaimana peran BPOM dalam pengawasan peredaran jamu tradisional yang mengandung bahan kimia berbahaya di masyarakat? (2) Bagaimana perlindungan hukum terhadap masyarakat terhadap beredarnya jamu tradisional yang mengandung bahan kimia berbahaya menurut Undang-Undang Nomor 8 Tahun 1999 Tentang Perlindungan Konsumen? Mengacu pada perumusan masalah, maka tipe penelitian yang digunakan dalam penulisan adalah penelitian normatif. Pengawasan yang dilakukan oleh BPOM terhadap peredaran jamu tradisional dilakukan baik terhadap kegiatan produksi dimana produk belum beredar maupun pengawasan terhadap produk yang telah beredar dipasaran. Tujuan hukum dari perlindungan hukum represif adalah untuk menyelesaikan sengketa. Upaya hukum preventif yang dilakukan BPOM dalam pengawasan jamu tradisional dapat berupa pembinaan dan kebijakan peningkatan mutu dengan memberlakukan standardisasi mutu produksi.

Kata Kunci: Jamu Tradisional, Perlindungan Konsumen, BPOM

\section{Pendahuluan}

Pada saat ini peningkatan konsumsi obat herbal atau juga jamu meningkat drastis, hal ini disebabkan khasiat dari pada jamu tersebut telah banyak terbukti untuk menyembuhkan atau memberikan daya terapi terhadap penyakitpenyakit ganas di era modern ini. Namun, 
ketidaktahuan dari konsumen jamu akan kandungan jamu yang beredar di masyarakat menimbulkan kecemasan tersendiri. Hal ini dikarenakan bentuk branding iklan yang dipergunakan jamu dalam mempromosikan produknya kadang membuat konsumen percaya dan langsung mengkonsumsi jamu tersebut tanpa memperhatikan kandungan komposisi di dalamnya.

Berdasarkan penelitian yang digunakan oleh para ahli makanan dan minuman baik di tingkat nasional atau internasional membuktikan bahwa mengkonsumsi jamu secara rutin dapat meningkatkan daya tahan tubuh terhadap serangan penyakit. Selain karena khasiatnya, jamu tradisional yang dibuat berdasarkan atas resep dan ramuan leluhur juga memiliki harga yang terjangkau bagi segala kalangan sehingga sangat menarik untuk dikonsumsi. Selain itu obat tradisional pada saat ini banyak digunakan karena menurut beberapa penelitian tidak terlalu menyebabkan efek samping, karena masih bisa dicerna oleh tubuh.

Obat tradisional di Indonesia atau jamu sudah dikenal sejak lama, dan memang mengandung bahan-bahan yang berkhasiat bagi kesehatan manusia, jika isinya benar-benar ramuan tradisional seperti bahan yang diramu dari tumbuh-tumbuhan, hewan maupun bahan mineral alami. Konsumsi jamu tradisional telah dilakukan oleh masyarakat Indonesia sejak lama, karena dikenal dengan khasiatnya yang dapat meningkatkan metabolisme tubuh dan bahkan ada yang memang sebagai obat dalam proses penyembuhan penyakit.

Dengan banyaknya peredaran makanan dan minuman saat ini serta makin banyaknya produsen yang nakal mempergunakan bahanbahan yang sehrusnya bukan untuk dikonsumsi, maka perlu suatu sistem yang dipergunakan untuk melindungi dan menjamin dari masyarakat sebagai konsumen. Berdasarkan hal tersebut maka dibentuklah lembaga oleh Pemerintah Indonesia, guna mengawasi dan mengontrol peredaran makanan, minuman dan lain sebagainya yang dikonsumsi oleh masyarakat yakni Badan Pengawas Obat dan Makanan (BPOM). BPOM memiliki salah satu kewenangannya adalah untuk mengawasi dan menegakkan pengawasan terhadap produk yang diketahui dan terbukti menggunakan Bahan Kimia Obat (BKO).

Penggunaan BKO ini menimbulkan kecemasan yakni dengan temuan bahwa beberapa jamu tradisonal diketahui mengandung BKO. Bukan yang pertama kali BPOM menarik obat tradisional dari peredaran.
Seperti halnya yang baru-baru ini terjadi tepatnya pada tanggal 6 Oktober 2018, sebanyak 21 macam obat tradisional dan suplemen berkhasiat menambah stamina pria ditarik dari peredaran.

Dengan adanya temuan dari BPOM terkait beberapa jamu tradisional yang diperjualbelikan di pasaran yang mengandung $\mathrm{BKO}$, hal ini membuat masyarakat benar-benar resah terutama mereka yang menjadikan jamu tradisional sebagai minuman rutin dan juga obat. Permasalahan ini tidak terlepas dari ketidaktahuan konsumen dalam memilih jamu tradisional yang tidak mengandung BKO namun diluar itu yang terpenting adalah adanya pengawasan dari pemerintah yang belum maksimal sehingga banyaknya peredaran jamu teradional yang mengandung BKO di pasaran.

Dalam hal ini BPOM memiliki posisi yang strategis dalam penanganan terhadap masalah diatas. Antisiapsi dan pencegahan yang dilakukan BPOM dapat berupa dengan pencegahan sebelum obat tersebut diproduksi yang dikaitkan dengan izin produksi, pengawasan dan penindakan yang dilakukan saat produk jamu telah ada dipasaran dengan pengecekan rutin, dan penguatan pengetahuan masyarakat dengan melakukan sosialisasi. Persoalan ini harus mendapat perhatian serius dari pemerintah jika masalah ini dibiarkan maka akan menimbulkan dampak yang semakin kompleks. Pelanggaran yang terjadi dilakukan tindakan secara projustitia, proses tindakan projustitia dimulai pelaporan dari pihak-pihak yang mengetahui dilakukannya tindak pidana tersebut, kemudian dilakulan penyelidikan, penyidikan, penuntutan dan proses pidana (Sutedi, 2008).

Penelitian sejenis sudah pernah dilakukan sebelumnya oleh (Haerandi, 2020), Hasil penelitiannya menunjukan bahwa peran badan pengawas obat dan makanan terkaitperedaran obat tradisional ilegal di kota makassar kurang berjalan dengan baik. Untuk mencengah peredaran obat tradisional ilegal di kota makassar, maka pihak BPOM harus lebih meningkatkan kinerja dengan cara rutin melakukan pemeriksaan untuk mengawasi peredaran obat tradisional ilegal. Ditambahkan lagi, Hendaknya BPOM sebagai pihak yang bertanggung jawab dalam peredaraan obat tradisional ilegal harus lebih telitih terhadap peredaran obat tradisional ilegal, baik sebelum diedarkan dan/atau setelah beredar di pasaran. Penelitian lainnya oleh (Zuhaid, Turisno, \& Suharto, 2016) mengemukakan Izin edar merupakan pengawasan preventif sebagai bentuk perlindungan bagi konsumen yang 
dilakukan oleh Badan Pengawas Obat dan Makanan sebelum obat beredar dimasyarakat. Jadi patut diduga jika obat tidak mempunyai izin edar, obat tersebut tidak teruji aspek keamanan, khasiat, dan mutu obatnya.

Sebagaimana telah diuraikan diatas, sebagai acuan dalam pembahasan tersebut maka dapat dirumuskan permasalahan yang akan dianalisis dalam penelitian ini adalah peran BPOM dalam pengawasan peredaran jamu tradisional yang mengandung bahan kimia berbahaya dan perlindungan hukum terhadap konsumen jamu tradisional yang mengandung bahan kimia berbahaya.

\section{Metode}

Metode penelitian yang diterapkan dalam penelitian ini adalah jenis penelitian hukum normatif. Penelitian hukum normatif didasarkan kepada penelitian kepustakaan atau dengan menggunakan bahan hukum sekunder lainnya (Soekanto \& Mamudji, 1995). Dalam melakukan penelitian hukum normatif, bahan hukum yang digunakan, yaitu: Bahan hukum primer terdiri dari perundang-undangan, catatan resmi atau risalah dalam pembuatan perundangundangan dan putusan-putusan hakim yang telah mendapatkan keputusan hukum tetap. Kedua, Bahan hukum sekunder yang terutama adalah buku teks yang berisi mengenai prinsipprinsip dasar ilmu hukum dan pandanganpandangan klasik para sarjana (Sedarmayanti \& Hidayat, 2002). Disamping buku teks, bahan hukum lainnya dapat berupa tulisan-tulisan tentang hukum baik dalam bentuk buku atau pun jurnal-jurnal. Penggunaan bahan hukum sekunder dirujuk kepada buku, jurnal, dan lain sebagainya bahan hukum tertulis berkaitan dengan perlindungan hukum terhadap konsumen. Ketiga, Bahan hukum tersier adalah bahan hukum yang memberikan petunjuk atau penjelasan terhadap bahan hukum primer dan bahan hukum sekunder seperti kamus hukum, encyclopedia, dan lain lain Bahan hukum tersier yang digunakan dalam penelitian ini adalah kamus Bahasa Indonesia, Kamus Hukum, media massa, dan lain-lain sebagai penunjang.

Teknik pengumpulan bahan hukum yang digunakan dalam penelitian ini yaitu Teknik studi dokumen, digunakan dengan cara melakukan pencatatan terhadap sumber bahan hukum primer dan bahan hukum sekunder kemudian akan dilakukan melalui penelusuran melalui kepustakaan yang berkaitan dengan perlindungan hukum terhadap konsumen. Kedua, Studi Kepustakaan, yaitu teknik mengumpulkan data dengan melakukan studi penelaahan terhadap buku, catatan yang ada hubungannya dengan masalah yang hendak dipecahakan. Ketiga, Studi Internet, yaitu teknik mengumpulkan data dengan melakukan pencarian kata kunci mengenai masalah yang hendak dipecahkan dalam suatu penelitian yang dilakukan melalui internet.

Metode yang digunakan dalam pengolahan bahan hukum, yaitu metode analisis data deksriptif analitis yang mengacu pada suatu masalah tertentu dan dikaitkan dengan pendapat para pakar hukum maupun berdasarkan peraturan perundang-undangan yang berlaku. Penggunaan anlisis deskriptif adalah dengan memberikan suatu gambaran yang komprehensif dan juga sistematis terhadap isu hukum yang diteliti.

\section{Hasil dan Pembahasan}

\section{Peran BPOM dalam Pengawasan dan Peredaran Jamu Tradisional yang Mengandung Bahan Kimia Berbahaya di Masyarakat}

Dalam memberikan perlindungan hukum kepada masyarakat sebagai konsumen maka perlulah diberlakukan perlindungan hukum bahkan sejak proses produksi. Proses produksi ditekankan yakni dengan penerapan Cara Pembuatan Obat Tradisionan yang Baik (CPOTB). CPOTB menekankan dalam proses produksi yakni dengan penjamin mutu dari campuran dan komposisi jamu tradisional yang diproduksi. Penjamin mutu yang dilakukan dari pemilihan bahan baku dengan standar yang telah ditentukan, selanjutnya dalam proses peramuan bahan baku yang akan menjadi jamu, dan proses pengemasan yang dilakukan secara higinis. Sehingga produk jamu tradisional yang diproduksi memiliki kualitas yang baik dan memang berkhasiat untuk dikonsumsi.

Salah satu bentuk ketegasan terhadap pelanggaran yang dilakukan oleh produsen adalah dengan penarikan kembali produk yang telah dipasarkan hal ini dilakukan karena tidak dipenuhi syarat mutu kualitas produk yang dipasarkan ke masyarakat. Hal tersebut tentunya sekaligus sebagai bentuk ketegasan dari pemerintah dalam hal ini BPOM untuk melindungi hak konsumen dari bentuk-bentuk kecurangan yang dilakukan oleh produsen.

Dalam prosedur yang diterapkan oleh BPOM, terkait dengan pengawasan dalam proses post-market, didasarkan yakni dengan:

\section{a. Pengawasan Produksi dan Distribusi}

Dalam pengawasan produksi, setelah 
produsen memperoleh izin produksi, maka BPOM melakukan pengawasan dengan memeriksa proses produksi langsung ke lokasi. Hal ini dilakukan untuk menjamin bahwa produksi yang dilakukan telah sesuai dengan standar yang diterapkan, dalam pemeriksaan ini minimal dilakukan setahun sekali namun jika ditemukan penyimpangan dalam implementasi baik CPOTB maupun GMP nya maka pemeriksaan dilakukan secara intensif hingga produsen melakukan perbaikan pada kegiatan produksinya.

Dalam pemeriksaan sarana distribusi BPOM melaksanakan pemeriksanaan langsung yang dilakukan dengan metode sampel acak yang pada sarana distribusi yang ada di wilayah -wilayah produksi. Dalam pemeriksaan ini, jika ditemukan obat tradisional berbahaya maka BPOM akan menindak dengan melakukan pemberian peringatan kepada pemilik sarana distribusi hingga melakukan penyitaan produk yang diduga berbahaya/ dilarang (Miru \& Yodo, 2004).

\section{b. Pemeriksaan sampling}

Dalam melakukan pengawasan di sarana distribusi BPOM juga melakukan pembelian produk pada saat melakukan pengawasan/ pemeriksaan langsung dilapangan guna pemeriksaan sampling, pengujian sampling dilakukan di laboratorium BPOM. Terhadap hasil pemeriksaan yang diketemukan mengandung $\mathrm{BKO}$ atau tidak memenuhi standar yang ada, maka BPOM akan mengambil tindakan tegas berupa teguran, peringatan dan penarikan produk yang diedarkan.

\section{c. Pengawasan iklan}

Pengawasan iklan merupakan pengawasan yang dilakukan oleh BPOM dalam mengawasi iklan yang dilakukan oleh produsen dalam memasarkan produknya (Miru \& Yodo, 2004). Pada dasarnya iklan yang dilakukan harus sesuai dengan produknya baik manfaatnya, komposisinya maupun visual yang disajikan baik dalam kemasan atau dalam media masa dan elektronik. Dalam pelaksanaannya pengawasan dilakukan dengan cara melihat pada kemasan produk dan media masa maupun elektronik.

\section{d. Public warning}

Public warning merupakan produk BPOM dalam memberikan informasi mengenai obat dan makanan melalui website BPOM RI terkait informasi baik mengenai produk apa saja yang memiliki izin edar, produk-produk ilegal, maupun berita seputar kegiatan BPOM diseluruh wilayah indonesia.

Pengawasan yang dilakukan oleh BPOM dari hulu sampai kehilir jadi sangat luas oleh karena itu perlu ada kerjasama yang baik antara penegak hukum dengan instansi terkait yang bertanggungjawab terhadap peredaran dan standar yang diberikan dalam produksi. Hal ini juga diutamakan dalam produk berupa obat, yang termasuk adalah obat herbal atau juga jamu tradisional, maka perlu adanya atensi yang tinggi terkait dengan mutu produk yang dijual kepada masyarakat. Masyarakat tidak mungkin menentukan standar mutu produk yang akan dibeli, maka tugas dari pemerintah melalui lembaga-lembaga yang berwenang untuk mulai menegaskan kepada para pihak produsen untuk menigkatkan kualitas dan mutu produk yang mereka jual ke pasaran.

\section{Perlindungan Hukum Terhadap Konsumen Jamu Tradisional}

Hukum merupakan suatu sistem yang penting dalam pelaksanaan rangkaian kewenangan dan kekuasaan kelembagaan Negara dan Pemerintah dalam aspek yang sempit (Hassanah, 2005). Hukum difungsikan sebagai bingkai dan batasan pemerintah dalam menentukan kebijakan hukum atau politik hukum guna memajukan dan memberikan perlindungan hukum, kepastian hukum, keadilan dan kemanfaatan hukum bagi seluruh manusia serta menegakkan hak asasi manusia.

Perlindungan hukum bermakna bahwa subjek hukum mendapatkan imunitas terkait dengan perlindungan akan hak-haknya sebagai seorang manusia. Perlindungan hak tersebut dipergunakan agar tidak adanya kesewenangwenangan yang dilakukan oleh pihak-pihak tertentu, sehingga kaidah hukum dan norma yang ada memberikan jaminan terhadap hak subjek hukum. Jika dikaitkan dengan konsumen, maka perlindungan hukum konsumen diartikan sebagai pemenuhan terhap hak-hak yang dimiliki konsumen yang diakibatkan karena suatu hal yang menyebabkan hak-hak tersebut tidak terpenuhi (Hadjon, 1987).

Undang-undang perlindungan konsumen ini juga menjamin adanya kepastian hukum bagi konsumen. Perlindungan konsumen memiliki cakupan yang sangat luas, meliputi perlindungan konsumen terhadap barang dan jasa, yang berawal dari tahap kegiatan untuk mendapatkan barang dan jasa hingga sampai akibat-akibat dari pemakaian barang dan/ atau jasa tersebut. Perlindungan hukum bersifat 
preventif dimaksudkan yang diberikan oleh pemerintah dengan tujuan untuk mencegah sebelum terjadinya pelanggaran. Hal tersebut biasanya terdapat dalam isi peraturan perundang-undangan dengan tujuan agar tidak dilanggarnya suatu batasan hukum yang dilakukan oleh masyarakat.

Bentuk perlindungan hukum yang diberikan kepada konsumen jamu tradisional berupa bentuk perlindungan hukum preventif dan perlindungan represif. Perlindungan hukum preventif bersifat pencegahan yang dilakukan BPOM dan lembaga terkait dengan peredaran jamu tradisional di masyarakat, juga dapat dengan memberikan sosialisasi terkait dengan konsumsi dan produk jamu tradisional.

Sedangkan perlindungan hukum represif dilakukan dengan sanksi tegas yang diberikan kepada produsen yang memproduksi jamu tradisional oleh BPOM atau lembaga terkait, bentuk sanksi dapat berupa sanksi administrasi dari pencabutan izin produksi sampai dengan izin usaha dari produsen jamu tadisional. Ada pula sanksi berupa jalur perdata yang dipergunakan untuk memberikan efek jera pada produsen yang memproduksi obat jamu berbahaya, dengan memberikan sanksi denda atas kerugian yang diderita oleh konsumen.

Dengan sanksi juga berupa sanksi pidana apabila memang terbukti adanya bentuk kecurangan yang membahayakan konsumen. Bentuk sanksi pidana tersebut merupakan pilihan akhir yang dilakukan sehingga produsen memang harus bertanggungjawab terhadap bentuk kecurangan yang dilakukannya. Hal tersebut memang pantas diberikan apabila terbukti dalam komposisi produk jamu tradisional yang dipasarkan mengandung $\mathrm{BKO}$ yang membahayakan kesehatan konsumen.

Upaya hukum preventif yang dilakukan BPOM dalam pengawasan jamu tradisional dapat berupa pembinaan dan kebijakan peningkatan mutu dengan memberlakukan standardisasi mutu produksi. Keberadaan perlindungan hukum preventif tertuang dalam Undang-undang Perlindungan Konsumen yang bertujuan agar memberikan keadilan dan kepastian hukum terhadap produk barang dan/ atau jasa yang diberikan atau diproduksi oleh produsen sehingga memberikan manfaat kepada konsumennya. Serta agar tidak melanggar segala ketentuan norma hukum yang telah ada terkait dengan asas keseimbangan sebagai penjual dan pembeli.

Perlunya upaya akan meningkatkan kesadaran konsumen terkait dengan hak-haknya sebagai konsumen. Maka tidak lepaslah hal tersebut dengan pengetahuan dan kesadaran konsumen dalam memilih produk yang akan dikonsumsi datai dipergunakan. Pemerintah juga menyediakan suatu badan untuk membantu para konsumen dalam menyelesaikan sengketanya dengan pelaku usaha yang dapat dilakukan dengan penyelesaian sengketa diluar pengadilan.

Dapat dilihat pada UUPK tidak memberikan definisi tentang sengketa konsumen. Namun yang pasti namanya sengketa bisa saja terjadi antara konsumen dengan pelaku usaha. Suatu sengketa dapat mengakibatkan kerugian bagi konsumen maupun pelaku usaha. Dengan demikian suatu permasalahan atau sengketa yang menyangkut para pihak harus dapat diselesaikan. Suatu sengketa konsumen berdasarkan UUPK dapat diselesaikan dengan 2 cara yaitu:

\section{a. Litigasi/ Pengadilan}

Setiap konsumen yang dirugikan atau terlibat pada suatu sengketa dapat menyelesaikan sengketanya melalui lembaga peradilan umum. Penyelesaian sengketa terhadap konsumen melalui pengadilan ini merujuk pada ketentuan tentang peradilan umum yang berlaku dengan memperhatikan ketentuan Pasal 45 UUPK. Namun penyelesaian secara litigasi merupakan penyelesaian dalam pilihan terakhir hal ini dikarenakan juga terkait dengan biaya dan waktu yang dikeluarkan sangat banyak dan terkadang malah merugikan dari pada kedua belah pihak.

\section{b. Non Litigasi/ Diluar Pengadilan}

Badan Penyelesaian Sengketa Konsumen (selanjutnya disebut BPSK) untuk mengembangkan upaya perlindungan konsumen dibentuklah badan tersebut. Salah satu tugas BPSK adalah memberikan saran dan rekomendasi kepada pemerintah dalam rangka menyusun kebijaksanaan di bidang perlindungan nasional. BPSK mempunyai tugas yaitu menangani penyelesaian sengketa konsumen dengan konsumen dengan cara mediasi atau konsilidasi atau arbitrase.

\section{Simpulan}

Pelaksanaan peran BPOM dalam pengawasan peredaran jamu tradisional yang mengandung bahan kimia berbahaya terhadap peredaran jamu tradisional, dalam memberikan perlindungan hukum kepada masyarakat sebagai konsumen maka perlulah diberlakukan perlindungan hukum bahkan sejak proses produksi. Proses produksi ditekankan yakni 
dengan penerapan Cara Pembuatan Obat Tradisionan yang Baik (CPOTB). CPOTB menekankan dalam proses produksi yakni dengan penjamin mutu dari campuran dan komposisi jamu tradisional yang diproduksi. Pengawasan yang dilakukan oleh BPOM dalam mengawasi iklan yang dilakukan oleh produsen dalam memasarkan produknya dan public warning, produk BPOM dalam memberikan informasi mengenai obat dan makanan melalui website BPOM RI.

Perlindungan hukum kepada konsumen terhadap beredarnya jamu tradisional yang mengandung bahan kimia obat, dilakukan dengan upaya hukum preventif yang dilakukan BPOM dalam pengawasan jamu tradisional dapat berupa pembinaan dan kebijakan peningkatan mutu dengan memberlakukan standardisasi mutu produksi; dan BPOM dengan kewenangan represif yaitu kewenagan yang biasa juga disebut kewenangan postmarket adalah kewenangan BPOM untuk mengadakan pemeriksaan terhadap produk obat dan makanan yang beredar di masyarakat, juga dalam UUPK terdapat penyelesaian sengketa konsumen bersifat represif yakni melalui litigasi atau non litigasi.

Pemerintah, selaku regulator dapat mengeluarkan produk peraturan perundangundangan guna menguatkan kinerja pengawasan dan pemeriksaan BPOM, terkhusus kepada jenis-jenis produk jamu tradisional mengingat jamu tradisional merupakan produk yang diproduksi masyarakat terkadang kurang higenis dan adanya BKO yang berbahaya bagi kesehatan tubuh;

Masyarakat, sebagai konsumen harus cerdas dalam mengkonsumsi produk jamu tradisional, selalu perhatikan kemasan apakah terdapat label atau tanda yang memang menyatakan bahwa produk jamu tradisional tersebut aman dikomsumsi. Selain itu masyarakat dapat saja membuat obat tradisional berupa jamu dengan olahan sendiri yang lebih terjamin dan higenis serta tentunya berkhasiat.

\section{Daftar Pustaka}

Hadjon, P. M. (1987). Perlindungan Hukum Bagi Rakyat Indonesia. Surabaya: Bina Ilmu. Retrieved from https:// trove.nla.gov.au/work/209862733

Haerandi, M. (2020). Perlindungan Konsumen Terhadap Peredaran Obat Tradisional Ilegal. Alauddin Law Develompent (ALDEV), 2(1), 6-11. Retrieved from http://journal.uin-alauddin.ac.id/ index.php/aldev/article/

download/13266/8216

Hassanah, H. (2005). Metode Alternatif Penyelesaian Sengketa. Bandung: Universitas Komputer.

Miru, A., \& Yodo, S. (2004). Hukum Perlindungan Konsumen. Jakarta: PT Raja Grafindo Persada. Retrieved from https://catalogue.nla.gov.au/ Record/3544735

Sedarmayanti, \& Hidayat, S. (2002). Metodelogi Penelitian. Bandung: Mandar Maju. Retrieved from http:// library.um.ac.id/free-contents/ index.php/buku/detail/metodologipenelitian-hj-sedarmayanti-syarifuddinhidayat-19560.html

Soekanto, S., \& Mamudji, S. (1995). Penelitian Hukum Normatif Suatu Tinjauan Singkat. Jakarta: PT Raja Grafindo Persada. Retrieved from https:// opac.perpusnas.go.id/DetailOpac.aspx? $\mathrm{id}=8027$

Sutedi, A. (2008). Tanggung Jawab Produk Dalam Hukum Perlindungan Konsumen. Bogor: Ghalia Indonesia. Retrieved from https:// catalogue.nla.gov.au/Record/4468112

Zuhaid, M. A. N., Turisno, B. E., \& Suharto, R. (2016). Perlindungan Konsumen Terhadap Peredaran Obat Tanpa Izin Edar Yang Dijual Secara Online Di Indonesia. Diponegoro Law Journal, 5 (3), 1-12. Retrieved from https:// media.neliti.com/media/ publications/19230-ID-perlindungankonsumen-terhadap-peredaran-obattanpa-izin-edar-yang-dijual-secara.pdf 